\title{
The Impact of Service Quality on Tourist Satisfaction: The Case Study of Rantau Abang Beach as a Turtle Sanctuary Destination
}

\author{
Tan Chi Hau \\ Khatijah Omar \\ Universiti Malaysia Terengganu, Malaysia \\ khatijah@umt.edu.my
}

Doi:10.5901/mjss.2014.v5n23p1827

\begin{abstract}
The study was conducted to investigate the causal relationship among the components of service quality (destination image, destination support services and security, destination cleanliness and destination facilities) and tourist satisfaction. A series of multiple regressions were applied to determine the relationship between service quality and tourist satisfaction. The results of the analysis confirmed that destination image, support services and security, cleanliness and facilities directly influenced tourist satisfaction. The results also indicated that service quality has a significant and positive impact on turist satisfactions. Thus, to ensure tourists' satisfaction, aggressive and sustained efforts should be undertaken to improve service quality.
\end{abstract}

Keywords: service quality, tourist satisfaction

\section{Introduction}

The complexity and globalization of today's competitive business environment have made quality one of the most important sources of competitive advantage in the tourism industry (Mohammed, 2006), and the evaluation of customer satisfaction is one way to determine the quality being. This effort is no exception in the Malaysian tourism sector. The diversity in terms of natural, cultural and historical resources is believed to support the growth of the tourism industry in Malaysia. One of the most common types of tourism is coastal tourism, which is based on a unique combination of resources at the interface of the land and sea, the annual pageants and water amenities, beaches, scenic beauty, rich terrestrial and marine biodiversity, diversified cultural and historic heritage, healthy food ,and, usually, good infrastructure. Thus, the quality of services offered should be at a competitive level so that Malaysia can compete with other ASEAN countries.

Rantau Abang Turtle Sanctuary is one of Malaysia's coastal tourism destinations. Since the 1960's, Rantau Abang was already known to most tourists as a Turtle Beach destination due to the beach being one of the six world famous hatching sites for giant leatherback turtles. Visitors from all over the world gather here from May to September every year (peak egg laying months are June and July) to experience this unique and amazing moment. The turtles travel as far as the Pacific Ocean and swim across to the Rantau Abang Beach to lay their eggs along the long stretch of beach. The beach terrain here is favorable as it has a steep and deep slope so that the turtles can 'land' straight on the beach.

The growing number of tourists each year has prompted the management of the Rantau Abang Turtle Sanctuary Authority Agency to exert extra effort to offer high service quality based on the understanding of tourists' perceptions and expectations, which in turn, can enhance the level of tourist satisfaction with the hope that this will increase their willingness to revisit the destination. Therefore, the investigation on the impact of service quality on tourist satisfaction at the Rantau Abang Turtle Sanctuary is relevant.

\section{Literature Review}

\subsection{Tourist Satisfaction}

Customer satisfaction plays an important role as a marketing tool to attract the most variable segments of the market. According to Bitner and Hubbert (1994), customer satisfaction is the term used for the measure of the extent to which the product or service provided by the organization meets customer expectations, or, in other words, customer satisfaction is 
the fulfilment of the wants, needs and expectations of customers, thereby create customer loyalty to the product or service offered. Pascoe (1983) also stated that customer satisfaction is the response concerning the state, the process and the result of the experience of services received. Therefore, satisfaction is important to successful destination marketing (Kozak \& Rimmimgton, 2000).In terms of tourism, tourists are customers who generate income for the country. Thus, in respect of continuing to develop the tourism sector emphasis should be given to the assessment of tourist satisfaction pertaining to the service quality provided.

\subsection{Relationship between Service Quality and Tourist Satisfaction}

A study by Mukhles (2013) concerning tourist satisfaction examined the impact of the quality of the tourism product on overall tourist satisfaction, and measured tourists' perceptions concerning the quality of tourism services provided at the Petra historical site. The findings noted that service quality, including destination facilities, destination accessibility and destination attraction, directly impacted tourist satisfaction. Another study conducted by Hossain and Leo (2008) revealed that service quality is a strong antecedent and is significantly related to customer satisfaction in the banking industry in Qatar. Similarly, Jihad and Majeda (2012) confirmed that service quality has a significant impact on tourist satisfaction.

Ivyanno and Nila (2013) examined the influence of service quality and tourist satisfaction on the future behavioral intentions of domestic local tourists to the Borobudur temple using the SERVQUAL model and multiple regression analysis. The study found that service quality has a positive influence on tourist satisfaction. In other words, maintaining service quality is important to maximize tourist satisfaction. Norazah (2013) found that five elements of service quality, assurance, reliability, responsiveness, tangibles and empathy are significantly correlated with tourist satisfaction in the hotel industry in Malaysia. While in the tourism industry, Perunjodi (2011) examined visitor satisfaction with respect to nature-based tourism attractions in Mauritius, and found that nature-based tourism attractions have significant impact on and positive relationship with the overall visitor satisfaction.

Bassey and Vivian (2009) conducted a study to investigate the relationship between tourists overall satisfaction and cultural festival attributes. Nine festivals attributes, organization, promotion, facilities, shopping, facilitates, refreshment, food, infrastructure, environmental ambience and safety and security, were investigated. Four of these nine attributes showed a significant relationship with overall satisfaction. Munir et al. (2013) investigated whether travelers were satisfied with their visit to Malaysia and also highlighted factors that contribute to tourist satisfaction. The results showed that the overall tourist satisfaction gave a mean score of 3.74. Among the factors that attracted tourists to visit the country were beautiful scenery, customs and culture, hospitality of the service providers, the quality of food and the friendliness of the local population. Ghazal (2012) also pointed out that tourists were satisfied with the tourism products and market in Uttaranchal.

\subsection{Hypothesis}

Based on the review of the literature, this study hypothesizes that:

$\mathrm{H1}$ : There is a positive relationship between the destination image and tourist satisfaction.

$\mathrm{H} 2$ : There is a positive relationship between the destination support services and security and tourist satisfaction.

H3: There is a positive relationship between the destination cleanliness and tourist satisfaction.

$\mathrm{H} 4$ : There is a positive relationship between the destination facilities and tourist satisfaction.

\section{Research Methodology}

\subsection{Pilot Study}

Usually, the total sample of respondents used in the pilot study is not less than 20 (Robert and Paul, 1996). In this study, a pilot study was conducted using 25 tourists visiting and arriving at the Rantau Abang Turtle Sanctuary. Those 25 travellers had voluntarily participated in the pilot study, thus producing a participation rate of 100 per cent. The Cronbach's alpha reliability coefficient value (a) was high at 0.865 .

\subsection{Population and Sample Size}

In the context of this study, quota sampling is suitably applied for determining the sample size where the total population 
is unknown (Tabachnick and Fidell, 2007). Therefore, quota sampling was used to determine the sample size for tourist respondents. A total of 165 samples were required comprising $92 \%$ local tourists and $8 \%$ foreign tourists. The sample in this study is travelers who have visited the Rantau Abang Turtle Sanctuary.

\subsection{Measurement Methods}

The study's questionnaire consisted of three parts, - tourist's demographic information, tourist satisfaction, and services quality including destination image, destination support services and security, destination cleanliness and destination facilities. The questionnaire for this study was adopted based on the studies of Norlida et al. (2011), Redzuan et al. (2010), and Ivyanno and Nila (2012), and modified for the topic of this study. The items were scored on a five-point Likert scale, 1 (one) for 'strongly disagree', 2 (two) for 'disagree' , 3 (three) for 'slightly agree', 4 (four) for 'agree' and 5 (five) for 'strongly agree'.

\subsection{Data Analysis}

Data analysis was undertaken using the Statistical Package for Social Sciences (SPSS). Percentage and frequency were used to explain the tourists; demographic information. Regression analysis is used when independent variables are correlated with one another and with the dependent variable (Sheridan J. Coakes, 2005). Therefore, regression analysis was applied to determine the relationship between tourist satisfaction and services quality. The regression model is as equation below:

$$
\begin{aligned}
& Y=\beta_{0}+\beta_{1} X_{1}+e \\
& \text { Where: } \\
& Y=\text { Tourist's satisfaction } \\
& \beta_{0}=\text { Intercept } \\
& \beta_{1}=\text { Regression coefficient } \\
& X_{1}=\text { Services quality } \\
& e=\text { Error term }
\end{aligned}
$$

\section{Findings and Discussion}

The descriptive statistical analysis provided an understanding of the distribution of the basic attributes of the participants. Table 1 shows the respondents demography of the respondents - (1) Gender: $53.9 \%$ of the subjects were male, and the rest $46.1 \%$ were female. (2) Age group: the main group was 30-39 years old, making up 34.5\%, followed by the 21-29 age group which constituted 27.9\%. (3) Education: secondary school education was the main group, taking up 41.2\%, followed by college/university education, taking up 33.3\%. (4) Income: most of the subjects (32.1\%) earned RM1,501RM2,000 a month, and 15.2\% of the subjects earned RM2,001-RM2,500 a month. (5) Profession: the largest group was formed by financial personnel, making up $29.1 \%$.

Table 1: Tourists' Demography

\begin{tabular}{|c|c|c|c|}
\hline Variables & Category & Frequency & Percentages (\%) \\
\hline \multirow{2}{*}{ Gender } & Male & 89 & 53.9 \\
& Female & 76 & 46.1 \\
\hline \multirow{4}{*}{ Age } & $<20$ & 5 & 3.0 \\
& $21-29$ & 46 & 27.9 \\
& $30-39$ & 57 & 34.5 \\
& $40-49$ & 39 & 23.6 \\
\multirow{4}{*}{ Education } & $>50$ & 18 & 10.9 \\
& Primary school & 41 & 24.8 \\
& Secondary school & 68 & 41.2 \\
& Collage/University & 55 & 33.3 \\
Monthly Income & Masters or other graduate degree & 4 & 2.4 \\
& $0-500 \mathrm{RM}$ & 14 & 8.5 \\
& $501-1000 \mathrm{RM}$ & 7 & 4.2 \\
\hline
\end{tabular}




\begin{tabular}{|c|c|c|c|}
\hline \multirow{5}{*}{} & $1501-2000$ RM & 53 & 32.1 \\
& $2001-2500$ RM & 25 & 15.2 \\
& $2501-3000$ RM & 10 & 6.1 \\
& $>3000$ RM & 15 & 9.1 \\
\hline \multirow{5}{*}{ Profession } & Administrative & 26 & 15.8 \\
& Engaged person in science, technology, culture or education & 11 & 6.7 \\
& Financial personal & 48 & 29.1 \\
& General worker & 32 & 19.4 \\
& Businessman & 35 & 21.1 \\
& Student & 11 & 6.7 \\
& Retiree & 2 & 1.2 \\
\hline
\end{tabular}

$n=165$

To measure the reliability of the questionnaire used, the Cronbach's alpha was applied to analyze the data collected. The results indicated that the Cronbach's alpha coefficient was $\alpha=0.853$ for destination image, $\alpha=0.721$ for destination support services and security, $a=0.782$ for destination cleanliness, $\alpha=0.744$ for destination facilities and $a=0.865$ for tourist satisfaction. Given that all of the measured values are above 0.60 , it can be concluded that there is a high consistency and reliability among the statements in questionnaire (DeVellis, 1991). The results of the reliability analysis are shown in Table 2.

Table 2: Reliability Analysis

\begin{tabular}{|l|c|c|}
\hline Variables & No. of Items & Cronbach's Alpha \\
\hline Destination image & 3 & 0.853 \\
\hline Destinationsupport services and security & 7 & 0.721 \\
\hline Destination cleanliness & 6 & 0.782 \\
\hline Destination facilities & 5 & 0.744 \\
\hline Tourist satisfaction & 3 & 0.865 \\
\hline The whole questionnaire & 24 & 0.881 \\
\hline
\end{tabular}

Table 3 below describes the value of the mean and standard deviations for each variable in the study's questionnaire. The findings showed that destination facilities was the highest mean (4.15) presenting its importance from the point of view of the sample individuals while destination support services and security was the lowest mean (3.87) indicating that the sample individuals consider it to be the least important. Tourist satisfaction, as a dependent variable, was expressed by a mean of 4.09 , which is considered as very good satisfaction.

Table 3: Means and Standard Deviations for Variables

\begin{tabular}{|l|c|c|c|}
\hline Service Quality & Mean & SD & Order \\
\hline Destination image & 3.99 & 0.64 & 3 \\
\hline Destinationsupport services and security & 3.87 & 0.58 & 4 \\
\hline Destination cleanliness & 4.03 & 0.67 & 2 \\
\hline Destination facilities & 4.15 & 0.71 & 1 \\
\hline Dependent Variable & Mean & SD & \\
\hline Tourist satisfaction & 4.09 & 0.63 & \\
\hline
\end{tabular}

Table 4 shows that destination image is a significant predictor of tourist satisfaction. The results indicated a positive relationship between the destination image and tourist satisfaction $(t=2.850, p=0.005)$. Consequently, hypothesis $\mathrm{H} 1$ is accepted. In addition, the study also showed a positive relationship between destination support services and security, and tourist satisfaction $(t=6.692, p=0.000)$. Therefore, in this study, destination support services and security positively influenced tourist satisfaction. Consequently, hypothesis $\mathrm{H} 2$ is accepted.

The regression results also showed that destination cleanliness is a significant predictor of tourist satisfaction. The results indicated a positive relationship between destination cleanliness and tourist satisfaction $(t=2.496, p=0.013)$. Consequently, hypothesis $\mathrm{H} 3$ is accepted. Furthermore, the study also showed a positive relationship between destination facilities and tourist satisfaction $(t=9.601, p=0.000)$. Therefore, in this study, destination facilities positively influenced tourist satisfaction. Consequently, hypothesis $\mathrm{H} 4$ is accepted. All the results seem to be consistent with 
Gounaris et al., (2003), Jay and Hsin (2007), Osman and Sentosa (2013), and Akbar and Parvez (2009) who concurred that service quality is positively associated with tourist satisfaction.

The R Square of 0.504 showed that the model is a fit one and that $50 \%$ of the deviations observed were caused by the independent variable in the model. The $p$-value for the overall model was significant at $p$-value $<0.05$.

Table 4: Regression Analysis for Impact of Service Quality on Tourist Satisfaction

\begin{tabular}{|c|c|c|c|c|c|}
\hline \multirow[t]{2}{*}{ Model } & \multicolumn{2}{|c|}{ Unstandardized Coefficients } & \multirow{2}{*}{$\begin{array}{c}\begin{array}{c}\text { Standardized } \\
\text { Coefficients }\end{array} \\
\text { Beta } \\
\end{array}$} & \multirow[t]{2}{*}{$t$} & \multirow[t]{2}{*}{ Sig. } \\
\hline & B & Std. Error & & & \\
\hline (Constant) & 3.199 & 0.044 & & 8.025 & 0.000 \\
\hline 1. Destination Image & 0.120 & 0.043 & 0.142 & 2.850 & $0.005^{*}$ \\
\hline 2. Destination support services and security & 0.413 & 0.063 & 0.378 & 6.692 & $0.000^{*}$ \\
\hline 3. Destination cleanliness & 0.165 & 0.062 & 0.145 & 2.496 & $0.013^{* *}$ \\
\hline 4. Destination facilities & 0.557 & 0.058 & 0.564 & 9.601 & $0.000 *$ \\
\hline
\end{tabular}

$\mathrm{R}^{2}=0.504 ;$ F-value $=10.473, p<0.000$

* Significant at 1\%, ** Significant at 5\%

\section{Conclusion}

In recognition that the quality of service is a factor that contributes to the attraction of tourists to a destination, a study concerning the perceptions of tourist satisfaction was undertaken. This study intended to measure the impact of service quality on tourist satisfaction.

Based on the high Cronbach's alpha, the mean and regression analysis could continue. The results from the mean analysis showed that tourists are satisfied with the four service components studied. Meanwhile, the results of the regression analysis showed that the service quality component which is destination image, destination support services and security, destination cleanliness and destination facilities, is significantly and positively related to tourist satisfaction.

Therefore, to ensure the continued visits tourists to the Rantau Abang Turtle Sanctuary, the initiative of offering sustained high service quality is important. Serious attention should be given especially by the management of Rantau Abang Turtle Sanctuary to services related to the environment. This is because the elements of the environment are vulnerable to tourist activities

\section{References}

Akbar, M. M. and Parvez, N. (2009).Impact of service quality, trust, and customer satisfaction on customer loyalty.ABAC Journal. 29(1): 24-38.

Bassey Benjamin Esu and Vivian Mbaze-Ebork Arrey (2009). Tourists' Satisfaction with Cultural Tourism Festival:a Case Study of Calabar Carnival Festival, Nigeria. International Journal of Business and Management, 4(3): 116-125.

Bitner, M. J. \& Hubbert, A. K. (1994). Encounters satisfaction versus overall satisfaction versus quality attributes of confidence, convenience, and price function of customers of financial services firms. Journal of Financial Services Marketing, 1-5.

DeVellis, R.F. (1991). Scale development: theory and applications. Newbury Park, California: Sage Publications.

Ghazal Masarrat (2012). Tourist's Satisfaction towards Tourism Products and Market: A Case Study of Uttaranchal. Int. J Busi. Inf. Tech., 2(1): 16-25.

Gounaris, S. P., Stathakopoulos, V. and Athanassopoulos, A. D. (2003). Antecedents to perceived service quality: an exploratory study in the banking industry. The International Journal of Bank Marketing.21(4/5): 168-190.

Ivyanno Canny and Nila Hidayat (2012). The Influence of Service Quality and Tourist Satisfaction on Future Behavioral Intentions: The Case Study of Borobudur Temple as a UNESCO World Culture Heritage Destination. IPEDR, 50(19): 89-97.

Jay, K. and Hsin, H.H. (2007). Do hoteliers need to manage image to retain loyal customers? International Journal of contemporary Hospitality Management, 19(6): 435-443.

Jihad and Majeda (2012).The Impact of Service Quality on Tourist Satisfaction in Jerash.Interdisciplinary Journal of Contemporary Research in Business, 3(12); 164-187.

Kozak, M. \&Rimmington, M. (2000).Tourist's satisfaction with Mall orca, Spain as an off-season holiday destination.Journal of Travel Research, 38:260-269.

Mohammed Hussain and Shirley, Leo (2008). Customer perception on service quality in retail banking in Middle East: the case of Qatar. International Journal of Islamic and Middle Eastern Finance and Management, 2(4): 338 - 350.

Mohammed I. Eraqi (2006). Tourism services quality(TourServQual) in Egypt: The viewpoints of external and internal customers. An International Journal, 13(4): 469-492. 
Munir Salleh, Khatijah Omar, Azizul Yadi Yaakop and Ahmad Ramli Mahmmod (2013).Tourist Satisfaction in Malaysia. International Journal of Business and Social Science, 4(5): 221-226.

Mukhles Al-Ababneh (2013). Service Quality and its impact on Tourist Satisfaction. Interdisciplinary Journal of Contemporary Research in Business, 4(12); 164-177.

Norazah Mohd Suki (2013). Examining the Correlations of Hotel Service Quality with Tourists Satisfaction. World Applied Sciences Journal, 21(12): 1816-1821.

Norlida, H.M.S., Redzuan, O., Kalsom, Z. \& Tamat, S. (2011). Pengukuran Kepuasan Pelancong terhadap Kualiti Perkhidmatan di Destinasi Pelancongan Pulau Kapas: Pendekatan Faktor Analisis.Malaysian Journal of Environmental Management,12(2): 23-32.

Osman, Z. and Sentosa, I (2013).Mediating effect of customer satisfaction on service quality and customer loyalty relationship in Malaysian rural tourism. International Journal of Economics and Management Studies, 2(1): 25-37.

Pascoe, G.C. (1983). Patient satisfaction in primary health care: a literature review and analysis.Evaluation and Program Planning, 6(34): $185-210$.

Perunjodi Naidoo (2011). An Assessment of Visitor Satisfaction with Nature-Based Tourism Attractions.International Journal of Management and Marketing, 4(1): 87-98.

Redzuan Othman, Norlida Hanim Mohd Salleh, Tamat Sarmidi, Nor Ghani Mohd Noor Dan Kalsom Zakaria (2010). Kualiti Perkhidmatan Alam Sekitar Taman Laut Malaysia: Analisis Perbandingan Kepuasan Pelancong. Prosiding Perkem V, 2: 250 - 259.

Robert J. Mc Dermoott \& Paul D. Sarrela (1996). Health Education Evaluation and Measurement: A Practitioner's Perspective. 2nd Edition, New Jersey: Prentice Hall Englewood, h. 147-148.

Sheridan J. Coakes (2005). SPSS: v. 12: Analysis without Anguish Using SPSS.Publisher John Wiley \& Sons Australia Ltd. ISBN.

Tabachnick, B. G., \& Fidell, L. S. (2007). Using multivariate statistics(3rd ed.). New York: Harper Collins. 